\title{
USULAN RANCANGAN TATA LETAK GUDANG PENYIMPANAN KANTONG SEMEN MENGGUNAKAN METODE SHARED STORAGE
}

\author{
Meldia Fitri ${ }^{1}$ Dhianada Irsya Putri ${ }^{2}$ \\ ${ }^{1}$ Fakultas Teknik, Universitas Putra Indonesia "YPTK", Padang \\ email: meldiafitri25@gmail.com \\ ${ }^{2}$ Fakultas Teknik, Universitas Putra Indonesia "YPTK", Padang \\ email: dhianadairsya10@gmail.com
}

\begin{abstract}
There was a demand for certain types of cement bags (paper sacks) which increased resulting in the storage of goods in an empty area in another warehouse located in the Factory Operational Warehouse (OPS). This is because the cement bags (paper sacks) are placed randomly and the placement system of new arrivals is placed in an empty area, with no regard to the most widely used items placed at the entrance-exit so that the storage capacity is insufficient with capacity utilization warehouse is not optimal. Therefore, to solve this problem, the authors conducted a study by re-designing the layout of the cement bag warehouse with the shared storage method, namely by arranging storage areas based on the current condition of the cement bag warehouse floor, then sorting the areas closest to the area the furthest from the entrance-exit based on the most used items. From the results of the study obtained 3 storage areas in the cement bag warehouse 1, and 2 storage areas in the cement bag warehouse 2, with the preparation of a pallet consisting of 3 levels so that the space requirements can be optimized.
\end{abstract}

Keywords: Warehouse layout, Shared storage, Material handling distance

\begin{abstract}
Abstrak
Dalam suatu waktu terdapat permintaan jenis kantong semen (sak) tertentu yang meningkat mengakibatkan terjadinya penyimpanan barang pada area yang kosong di gudang lain yang berada di Gudang Operasional Pabrik (OPS). Hal tersebut disebabkan karena kantong semen (sak) diletakkan secara acak dan sistem penempatan barang yang baru datang, diletakkan pada area yang kosong, dengan tidak memperhatikan barang yang paling banyak dipakai yang diletakkan di pintu masuk-keluar sehingga kapasitas penyimpanan tidak mencukupi dengan pemanfaatan kapasitas gudang belum maksimal. Oleh karena itu untuk menyelesaikan permasalahan tersebut, maka penulis melakukan penelitian dengan merancang ulang tata letak gudang kantong semen metode shared storage, yaitu dengan menyusun area-area penyimpanan berdasarkan kondisi luas lantai gudang kantong semen saat ini, kemudian diurutkan area yang paling dekat dengan area yang terjauh dari pintu masuk-keluar berdasarkan barang yang paling banyak dipakai. Dari hasil penelitian diperoleh 3 area penyimpanan pada gudang kantong semen 1, dan 2 area penyimpanan pada gudang kantong semen 2, dengan penyusunan pallet yang terdiri dari 3 tingkat sehingga kebutuhan ruang dapat dioptimalkan.
\end{abstract}

Kata kunci: Tata letak gudang, Shared storage, Jarak material handling 


\section{PENDAHULUAN}

Setiap perusahaan dengan usaha produksi memiliki tujuan utama yaitu untuk memperoleh keberhasilan di dalam profit usahanya. Dalam mencapai tujuan tersebut akan diperlukan suatu perencanaan yang benar-benar harus dipersiapkan dan dirancang dengan baik. Pencapaian tujuan perusahaan dalam memperoleh keberhasilan di dalam profit usahanya perlu memperhatikan mengenai perencanaan tata letak pada usaha produksi yang bersangkutan. Perencanaan itu dapat meliputi bagaimana sebaiknya susunan bangunan yang akan digunakan agar sesuai dengan kegiatan perusahaan atau juga bagaimana sebaiknya pembagian dan penempatan ruang-ruang dan mesin atau peralatan kerja dan produksi. Dengan perencanaan serta perhitungan yang matang dan benar dalam suatu kegiatan produksi, misalnya dalam pengaturan mesin dan peralatan yang digunakan, maka akan dapat melancarkan dan memaksimalkan produksi sehingga dapat memperoleh keberhasilan di dalam profit usaha.

Perancangan fasilitas manufaktur merupakan suatu cara agar penggunaan peralatan, mesin, material, tenaga kerja dan energi dapat berlangsung efisien. Perancangan fasilitas merupakan salah satu istilah penting dalam penyusunan unsur fisik pabrik dan juga layanan jasa seperti pergudangan, kantor pos, toko, restoran, dan rumah sakit. Salah satu aspek yang penting dalam tata letak fasilitas pabrik adalah perancangan gudang. Dalam suatu industri manufaktur perancangan gudang merupakan salah satu hal yang harus diperhatikan. Gudang merupakan suatu area terpisah yang digunakan untuk menyimpan bahan baku, part, dan juga persediaan [1]. Dalam melakukan perancangan gudang salah satu hal yang harus diperhatikan adalah sistem penyimpanan yang baik dengan pemanfaatan tempat penyimpanan yang maksimal. Pengaturan tata letak penyimpanan yang baik akan mempengaruhi kelancaran operasi pergudangan. Selain itu, pengelompokan dan lokasi penyimpanan barang di gudang perlu diperhatikan juga sehingga pekerja dapat dengan mudah menemukan barang yang akan dicari dan dapat mengurangi waktu pencarian barang. Dengan pengaturan penyimpanan barang di gudang yang baik maka barang yang keluar dan masuk ke gudang akan berjalan dengan lancar.

PT. Semen Padang merupakan salah satu produsen semen terkemuka di Indonesia. Perusahaan ini memiliki Gudang Operasional Pabrik (OPS) yang berada di kawasan perusahaan yang terletak di Indarung, Lubuk Kilangan, Kota Padang. Area Gudang Operasional Pabrik (OPS) terdiri dari empat gudang diantaranya, dua gudang kantong semen (sak), satu gudang oli dan pelumas, serta satu gudang semen cor tahan api (castable). Pada gudang kantong semen (sak) terdiri dari tiga jenis kantong berdasarkan ukurannya, yaitu ukuran $40 \mathrm{~kg}, 50 \mathrm{~kg}$, dan 1 ton. Jenis kantong semen (paper sak) yang berada di area Gudang Operasional Pabrik (OPS) ini digunakan untuk jenis semen campuran, yang terdiri dari Portland Composite Cement (PCC), Ordinary Portland Cement (OPC) dan Oil Well Cement (OWC). Dalam suatu waktu terdapat permintaan jenis kantong semen (paper sak) tertentu yang meningkat mengakibatkan terjadinya penyimpanan barang pada area yang kosong di gudang lain yang berada di Gudang Operasional Pabrik (OPS). Hal tersebut disebabkan karena kantong semen (paper sak) diletakkan secara acak dan sistem penempatan barang yang baru datang, diletakkan pada area yang kosong, dengan tidak memperhatikan barang yang paling banyak dipakai yang diletakkan di pintu masuk-keluar sehingga kapasitas penyimpanan tidak mencukupi dengan pemanfaatan kapasitas gudang belum maksimal. Oleh karena itu untuk 
menyelesaikan permasalahan tersebut, maka penulis melakukan penelitian dengan merancang ulang tata letak gudang kantong semen untuk meningkatkan kapasitas gudang menggunakan metode shared storage, yaitu dengan menyusun area-area penyimpanan berdasarkan kondisi luas lantai gudang kantong semen saat ini, kemudian diurutkan area yang paling dekat dengan area yang terjauh dari pintu masuk-keluar berdasarkan barang yang paling banyak dipakai. Sehingga kapasitas gudang dapat ditingkatkan, dan tidak ada barang yang disimpan pada area yang kosong di gudang lain. Tujuan dalam penelitian ini adalah merancang ulang tata letak penempatan produk pada Gudang kantong semen di Gudang OPS PT. Semen Padang.

Tata letak pabrik atau tata letak fasilitas dapat didefinisikan sebagai tata cara pengaturan fasilitas-fasilitas pabrik guna menunjang kelancaran proses produksi. Pengaturan tersebut akan mencoba memanfaatkan luas area penempatan mesin atau fasilitas penunjang produksi lainnya, kelancaran gerakan perpindahan material, penyimpanan material baik yang bersifat temporer maupun permanen, personel kerja dan sebagainya. Pada dasarnya didalam desain tata letak pabrik adalah untuk meminimalkan total biaya yang antara lain menyangkut elemenelemen biaya seperti biaya pemindahan bahan, biaya kontruksi dan instalasi untuk bangunan mesin, biaya produksi, perbaikan, keamanan, biaya penyimpanan produk dan biaya lainnya [2].

Gudang dapat didefinisikan sebagai tempat yang dibebani tugas untuk menyimpan barang yang akan dipergunakan dalam produksi sampai barang diminta sesuai dengan jadwal produksi. Sejak dulu, gudang berfungsi sebagai buffer atau penyeimbang dan untuk menentukan langkah selanjutnya suatu perusahaan, apakah perusahaan akan menggunakan gudang untuk komersial atau lebih baik digunakan sendiri.
Selanjutnya, gudang sebagai penyimpanan produk jadi mempunyai beberapa misi dan tugas [3].

Material handling Mempunyai arti penanganan material dalam jumlah yang tepat dari material yang sesuai dalam kondisi yang baik pada tempat yang cocok, pada waktu yang tepat dalam posisi yang benar, dalam urutan yang sesuai dan biaya yang murah dengan menggunakan metode yang benar. jika digunakan metode yang sesuai, maka sistem material akan terjamin atau aman dan bebas dari kerusakan. Ada dua jenis material handling yaitu manual material handling dan material handling equipment [4][5]. Pengukuran jarak perpindahan bahan ditentukan oleh frekuensi perpindahan antar mesin atau fasilitas dan jarak antar mesin atau fasilitas. jarak yang telah ditentukan oleh ukuran mesin atau fasilitas dan teknik [6].

Tujuan dari penelitian ini adalah melakukan perancangan ulang pada Gudang kantong semen di gudang operasional pabrik (gudang OPS) PT. Semen Padang sehingga memaksimalkan kapasitas penyimpanan gudang dan menghilangkan aktivitas penyimpanan barang di area kosong gudang lain yang berada di gudang operasional pabrik (gudang OPS).

\section{METODE PENELITIAN}

Penelitian ini menggunakan jenis penelitian aplikasi model. Data yang digunakan dalam penelitian ini adalah data sekunder meliputi data jenis kantong semen, data penerimaan dan pengeluaran kantong semen, kapasitas gudang, gudang kantong semen, dimensi produk dan pallet, jarak dan dimensi material handling.

\section{HASIL DAN PEMBAHASAN}

3.1 Menentukan Jumlah Penerimaan dan Pengeluaran Produk Rata-Rata Per Bulan

Dalam menentukan jumlah permintaan produk rata-rata digunakan untuk 
mengetahui rata-rata permintaan jenis kantong semen tiap bulannya. Untuk memperoleh jumlah permintaan rata-rata masing-masing produk per bulan dapat dilihat pada tabel 1 .

Tabel 1. Jumlah Rata-Rata Penerimaan Kantong Semen Per Bulan

\begin{tabular}{|c|c|c|c|}
\hline \multirow{2}{*}{ No } & \multirow{2}{*}{$\begin{array}{c}\text { Jenis Kantong } \\
\text { Semen }\end{array}$} & \multicolumn{2}{|c|}{ Jumlah Rata-rata Produk } \\
\cline { 3 - 4 } & Penerimaan & Pengiriman \\
\hline 1 & $\begin{array}{c}\text { OPC Big Bag } 1 \\
\text { Ton }\end{array}$ & 4,420 & 7,349 \\
\hline 2 & OPC 50 Kg & 51,458 & 210,083 \\
\hline 3 & PCC 40 Kg & 898,951 & 810,175 \\
\hline 4 & PCC 50 Kg & $2,247,111$ & $1,978,394$ \\
\hline 5 & OWC 42,5 Kg & 0 & 608 \\
\hline
\end{tabular}

\subsection{Rata-Rata Frekuensi Pemesanan Tiap Jenis Produk Per Bulan}

Penentuan rata-rata frekuensi pemesanan tiap jenis kantong semen per bulan digunakan untuk mengetuhi berapa banyak pemesanan untuk tiap-tiap produk dalam 1 bulannya. Rata-rata frekuensi permintaan per bulan, dapat dilihat pada Tabel 2

Tabel 2. Rata-rata frekuensi permintaan per jenis kantong

\begin{tabular}{|c|c|c|c|c|c|c|}
\hline \multirow{2}{*}{$\begin{array}{c}\text { Jenis Kantong } \\
\text { Semen }\end{array}$} & \multicolumn{6}{|c|}{ Frekuensi Jumlah Permintaan Per } \\
\cline { 2 - 7 } & 1 & 2 & 3 & 4 & 5 & 6 \\
\hline $\begin{array}{c}\text { OPC Big Bag } 1 \\
\text { Ton }\end{array}$ & 10 & 6 & 11 & 9 & 17 & 11 \\
\hline OPC $50 \mathrm{Kg}$ & 3 & 0 & 0 & 3 & 1 & 0 \\
\hline PCC $40 \mathrm{Kg}$ & 26 & 16 & 19 & 18 & 30 & 18 \\
\hline PCC $50 \mathrm{Kg}$ & 12 & 9 & 52 & 41 & 32 & 23 \\
\hline OWC $42,5 \mathrm{Kg}$ & 0 & 0 & 0 & 0 & 0 & 0 \\
\hline
\end{tabular}

\begin{tabular}{|c|c|c|c|c|c|c|c|}
\hline \multirow{2}{*}{$\begin{array}{c}\text { Jenis } \\
\text { Kantong } \\
\text { Semen }\end{array}$} & \multicolumn{6}{|c|}{ Frekuensi Jumlah Permintaan } & \multirow{2}{*}{$\begin{array}{c}\text { A } \\
\text { v }\end{array}$} \\
\cline { 2 - 8 } & 7 & 8 & 9 & 10 & 11 & 12 & \\
\hline $\begin{array}{c}\text { OPC Big } \\
\text { Bag 1 Ton }\end{array}$ & 22 & 18 & 21 & 29 & 24 & 22 & $\begin{array}{l}1 \\
7\end{array}$ \\
\hline OPC 50 Kg & 3 & 2 & 4 & 10 & 4 & 4 & 3 \\
\hline PCC 40 Kg & 23 & 23 & 26 & 17 & 22 & 28 & $\begin{array}{c}2 \\
2\end{array}$ \\
\hline PCC 50 Kg & 46 & 48 & 50 & 35 & 49 & 42 & $\begin{array}{l}3 \\
7\end{array}$ \\
\hline $\begin{array}{c}\text { OWC 42,5 } \\
\text { Kg }\end{array}$ & 0 & 0 & 0 & 1 & 1 & 0 & 1 \\
\hline
\end{tabular}

\subsection{Jumlah Produk Per Pemesanan Tiap Jenis Produk Per Bulan}

Dengan mengetahui rata-rata frekuensi permintaan per bulan maka dapat ditentukan jumlah kantong semen tiap pemesanan untuk masing-masing jenis kantong semen. Jumlah kantong semen per pemesanan dapat di lihat pada Tabel 3.

Tabel 3. Jumlah Permintaan per Pemesanan

\begin{tabular}{|c|c|c|c|c|}
\hline $\begin{array}{c}\mathrm{N} \\
\mathrm{O}\end{array}$ & $\begin{array}{c}\text { Jenis } \\
\text { Kantong } \\
\text { Semen }\end{array}$ & $\begin{array}{c}\text { Jumlah } \\
\text { Permintaan } \\
\text { Rata-Rata } \\
\text { Per Bulan }\end{array}$ & $\begin{array}{c}\text { Frekuensi } \\
\text { Permintaa } \\
\text { n Rata- } \\
\text { Rata Per } \\
\text { Bulan }\end{array}$ & $\begin{array}{c}\text { Jumlah } \\
\text { Permintan } \\
\text { Per } \\
\text { Pemesana } \\
\text { n }\end{array}$ \\
\hline 1 & $\begin{array}{c}\text { OPC } \\
\text { Big Bag } \\
1 \text { Ton }\end{array}$ & 7,349 & 17 & 441 \\
\hline 2 & $\begin{array}{c}\text { OPC } 50 \\
\mathrm{Kg}\end{array}$ & 210,083 & 3 & 74,147 \\
\hline 3 & $\begin{array}{c}\mathrm{PCC} 40 \\
\mathrm{Kg}\end{array}$ & 810,175 & 22 & 36,549 \\
\hline 4 & $\begin{array}{c}\mathrm{PCC} 50 \\
\mathrm{Kg}\end{array}$ & $1,978,394$ & 37 & 54,079 \\
\hline 5 & $\begin{array}{c}\text { OWC } \\
42,5 \mathrm{Kg} \\
\end{array}$ & 608 & 1 & 608 \\
\hline \multicolumn{2}{|r|}{ Total } & $3,006,609$ & & \\
\hline
\end{tabular}

\subsection{Penentuan Luas Area Penyimpanan yang Dibutuhkan}

Satu area penyimpanan tergantung dari varian kantong semen dari 100 lembar kantong semen hingga 10.000 lembar kantong semen dalam satu kemasan penyimpanan, dengan penyusunan pallet yang terdiri dari 3 tingkat. Ini dilakukan untuk memudahkan penyusunan produk ke area penyimpanan dan untuk menghemat pemanfaatan ruang. Luas area penyimpanan Gudang kantong semen 1 adalah 51,84 $\mathrm{m}^{2}$ dan Gudang kantong semen 2 adalah25,92 $\mathrm{m}^{2}$. Kebutuhan pallet dan area penyimpanan dapat dilihat pada tabel 4 dan 5 . 


\section{Tabel 4. Kebutuhan Pallet Penyimpanan}

\begin{tabular}{|c|c|c|c|c|}
\hline $\begin{array}{c}\mathrm{N} \\
\mathrm{o}\end{array}$ & $\begin{array}{c}\text { Jenis Kantong } \\
\text { Semen }\end{array}$ & $\begin{array}{c}\text { Jumlah } \\
\text { Rata- } \\
\text { Rata } \\
\text { Permint } \\
\text { an } \\
\text { Pemesa } \\
\text { nan }\end{array}$ & $\begin{array}{c}\text { Lemba } \\
\text { ran Per } \\
\text { Pallet }\end{array}$ & $\begin{array}{c}\text { Kebutuh } \\
\text { an Pallet } \\
\text { Penyimp } \\
\text { anan }\end{array}$ \\
\hline 1 & $\begin{array}{c}\text { OPC Big Bag } \\
1 \text { Ton }\end{array}$ & 0 & 200 & 51 \\
\hline 2 & OPC 50 Kg & 0 & 7,500 & 30 \\
\hline 3 & PCC 40 Kg & 0 & 10,000 & 88 \\
\hline 4 & PCC 50 Kg & 0 & 9000 & 222 \\
\hline 5 & $\begin{array}{c}\text { OWC 42,5 } \\
\text { Kg }\end{array}$ & 0 & 300 & 0 \\
\hline \multicolumn{5}{|c|}{ Total } \\
\hline
\end{tabular}

Tabel 5. Kebutuhan Area Penyimpanan

\begin{tabular}{|c|c|c|c|c|}
\hline $\begin{array}{c}\text { N } \\
\mathrm{o}\end{array}$ & $\begin{array}{c}\text { Jenis Kantong } \\
\text { Semen }\end{array}$ & $\begin{array}{c}\text { Kebutuh } \\
\text { an } \\
\text { Jumlah } \\
\text { Pallet }\end{array}$ & $\begin{array}{c}\text { Banyakn } \\
\text { ya } \\
\text { Pallet } \\
\text { dalam } 1 \\
\text { area }\end{array}$ & $\begin{array}{c}\text { Kebutuha } \\
\text { n Area } \\
\text { Penyimpa } \\
\text { nan }\end{array}$ \\
\hline 1 & $\begin{array}{c}\text { OPC Big Bag } 1 \\
\text { Ton }\end{array}$ & 51 & $9 \times 2 \times 3$ & 1 \\
\hline 2 & OPC 50 Kg & 30 & $5 \times 2 \times 3$ & 1 \\
\hline 3 & PCC $40 \mathrm{Kg}$ & 88 & $9 \times 4 \times 3$ & 1 \\
\hline 4 & PCC $50 \mathrm{Kg}$ & 222 & $9 \times 4 \times 3$ & 2 \\
\hline 5 & OWC $42,5 \mathrm{Kg}$ & 2 & $9 \times 4 \times 3$ & 1 \\
\hline
\end{tabular}

\subsection{Penentuan Allowance Ruang}

Penentuan luas gang yang diperlukan adalah berdasarkan dimensi terpanjang yaitu diagonal yang ada pada forklift saat membawa produk. Dengan mengetahui allowance yang diperlukan maka dapat ditentukan lebar gang adalah 2,7 m. Berikut ini gambar forklift saat membawa produk dapat dilihat pada Gambar 1.

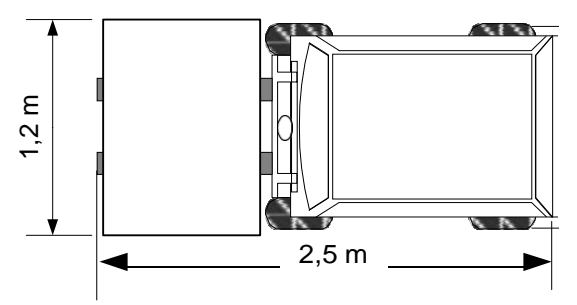

Gambar 1. Forklift Saat Membawa Produk

\subsection{Jarak Tempuh Material Handling Menggunakan Tata Letak Gudang Usulan}

Total jarak tempuh didapatkan dari jarak per jenis kantong semen dan frekuensi perpindahan. Adapun jarak tempuh material handling menggunakan tata letak usulan pada tabel 6 berikut ini.

Tabel 6. Jarak Tempuh Material Handling Tata Letak Usulan

\begin{tabular}{|c|c|c|c|c|}
\hline $\begin{array}{c}\mathrm{N} \\
\mathrm{o}\end{array}$ & $\begin{array}{c}\text { Jenis } \\
\text { Kantong } \\
\text { Semen }\end{array}$ & $\begin{array}{c}\text { Jarak } \\
(\mathrm{m})\end{array}$ & $\begin{array}{c}\text { Total } \\
\text { Frekuensi } \\
\text { Perpindaha } \\
\mathrm{n}\end{array}$ & $\begin{array}{c}\text { Jarak } \\
\text { Tempuh } \\
\text { Total } \\
(\mathrm{m})\end{array}$ \\
\hline 1 & $\begin{array}{c}\text { OPC Big } \\
\text { Bag 1 Ton }\end{array}$ & 19.4 & 59 & 1,142 \\
\hline 2 & $\begin{array}{c}\text { OPC 50 } \\
\mathrm{Kg}\end{array}$ & 6.3 & 35 & 220 \\
\hline 3 & $\begin{array}{c}\mathrm{PCC} \mathrm{40} \\
\mathrm{Kg}\end{array}$ & 2.6 & 171 & 444 \\
\hline 4 & $\begin{array}{c}\mathrm{PCC} \mathrm{50} \\
\mathrm{Kg}\end{array}$ & 29 & 470 & 13,616 \\
\hline 5 & $\begin{array}{c}\text { OWC 42,5 } \\
\mathrm{Kg}\end{array}$ & 2.6 & 2 & 5 \\
\hline \multicolumn{4}{|c}{} \\
\hline
\end{tabular}

\subsection{Rancangan Perbaikan Tata Letak Layout Berdasarkan Usulan Letak Area}

Setelah menentukan letak area penyimpanan selanjutnya dilakukan rancangan perbaikan tata letak layout berdasarkan usulan letak area penyimpanan. Berikut rancangan tata letak penyimpanan usulan gudang kantong semen 1 dan gudang kantong semen 2 . Rancangan tata letak untuk Gudang 1 dan Gudang 2 dapat dilihat pada gambar 2 dan 3. 


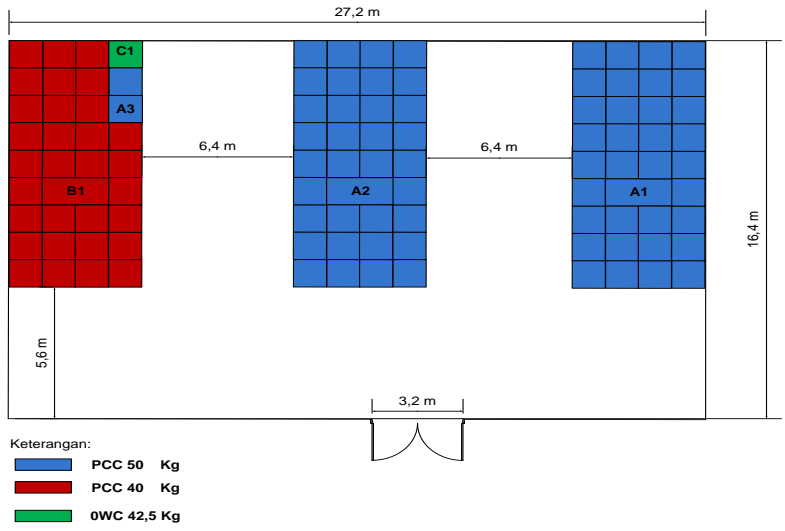

Gambar 2. Tata Letak Penyimpanan Usulan Gudang Kantong Semen 1

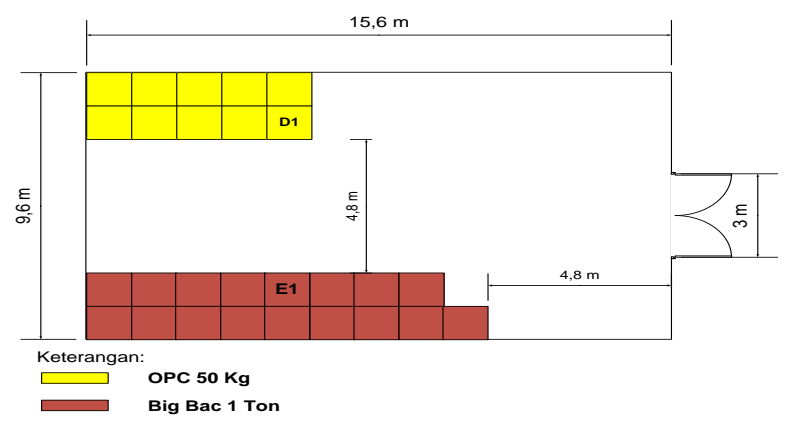

Gambar 3. Tata Letak Penyimpanan Usulan Gudang Kantong Semen 2

\section{SIMPULAN}

Berdasarkan rancangan ulang tata letak penempatan produk pada gudang kantong semen di gudang operasional pabrik (Gudang OPS) PT. Semen Padang, terdapat 3 area penyimpanan pada gudang kantong semen 1, dan 2 area penyimpanan pada gudang kantong semen 2, dengan penyusunan pallet yang terdiri dari 3 tingkat sehingga kebutuhan ruang dapat dioptimalkan dan lebar gang yang diperlukan adalah 5,4 meter agar memudahkan jalan nya material handling.
Setelah dilakukan perhitungan jarak tempuh material handling yang terjadi dalam gudang kantong semen di PT. Semen Padang, tata letak usulan memiliki total jarak tempuh yang lebih kecil daripada tata letak awal dengan perbaikan susunan dan tata letak penyimpanan. Total jarak tempuh tata letak awal adalah sebesar 15.849 meter. Total jarak tempuh tata letak usulan adalah sebesar 15.421 meter. Terjadi selisih nilai total jarak tempuh sebesar 428 meter dari total jarak tempuh awal. Hal ini berarti tata letak usulan dapat memperpendek jarak tempuh yang dilalui oleh karyawan gudang dalam mengambil barang.

\section{DAFTAR PUSTAKA}

[1] Wignjosoebroto, Sritomo. (2009). Tata Letak Pabrik dan Pemidahan Bahan. Surabaya: Penerbit Guna Widya.

[2] Arif, Muhammad. (2017). Perancangan Tata Letak Pabrik. Yogyakarta: Deepublish.

[3] Hadiguna, Rika Ampuh dan Heri Setiawan. (2008). Tata Letak Pabrik. Yogyakarta: Andi.

[4] Assauri, Sofyan. (2008). Manajemen Produksi dan Operasi. Edisi Revisi. Jakarta: Fakultas Ekonomi Universitas Indonesia.

[5] Nasution, A.H dan Prasetyawan, Y. (2008). Perencanaan dan Pengendalian Produksi. Edisi Pertama. Yogyakarta: Graha Ilmu

[6] Heizer, J., \& Render, B. (2009). Manajemen Operasi Edisi 9, Jakarta: Salemba Empat. 